\title{
My role and responsibility: mothers' perspectives on overload in caring for children with cancer*
}

\author{
Meu papel e responsabilidade: as perspectivas das mães \\ sobrecarregadas com o cuidado dos filhos com câncer \\ Mi rol y responsabilidad: las perspectivas de las madres \\ sobrecargadas con el cuidado a los hijos con cáncer
}

How to cite this article:

Vieira AC, Cunha MLR. My role and responsibility: mothers' perspectives on overload in caring for children with cancer. Rev Esc Enferm USP. 2020;54:e03540. DOI: http://dx.doi.org/10.1590/S1980-220X2018034603540

\section{Aretuza Cruz Vieira ${ }^{1}$}

Mariana Lucas da Rocha Cunha ${ }^{1}$

* Invited author WCQR, 2018.

${ }^{1}$ Faculdade Israelita de Ciências da Saúde Albert Einstein, Programa de Mestrado Profissional em Enfermagem, São Paulo, SP, Brazil.

\begin{abstract}
Objective: To understand the experience of maternal overload in caring for children with cancer from the mother's perspective. Method: Symbolic Interactionism was adopted as a theoretical framework and the Grounded Theory as methodological framework. The study was conducted in a public hospital, which is reference in pediatric oncology. Data was collected from six mothers through semi-structured interviews in the second semester of 2017. Results: Mothers of children with cancer attributed meaning to the care experience when trying to cope with the emotional, social, physical, financial, familyrelated, information and moral overload. Maternal overload arises as a dynamic interrelation process between the many types of overload. Conclusion: The maternal figure is the main person involved in care and experiences overload in caring for their sick child, facing limitations and responsibilities. The research acted as a key element to broaden the analysis and intervention of the family nurse, not only contributing to the theoretical construct related to maternal overload, but also and mainly to the scope of practice in patient care.
\end{abstract}

\section{DESCRIPTORS}

Child; Neoplasms; Mothers; Caregivers; Family Relations; Oncologic Nursing.
Corresponding author:

Aretuza Cruz Vieira

Rua Rio Grande, 551 - Ap.194 BI. A, Vila Mariana CEP 04018-001, São Paulo, SP, Brazil

arevitisp@gmail.com
Received: 08/09/2018

Approved: 04/11/2019 


\section{INTRODUCTION}

Similar to developed countries, cancer in Brazil already represents the first cause of death due to sickness in children and adolescents aged between 1 and 19 years old (representing $8 \%$ of the total) $)^{(1)}$. As important as the treatment of this pathology itself seen through the biomedical prism, there is also concern regarding the comprehensive care provided to these young hospitalized cancer patients and their families. The family is considered one of the supporting pillars for promoting well-being and assistance to these patients ${ }^{(2)}$.

Cancer diagnosis in a child invades the family and triggers destabilization in multiple aspects of family life. Thus, specific needs of these families arise from caring for a child with cancer and should be acknowledged in the scope of nursing care as a subsidy for practice ${ }^{(3-5)}$. Results of studies have revealed that the maternal figure is the main caregiver of a child who has cancer. They adjust their working hours or even abandon their jobs to do routine housework and to meet the needs of their child ${ }^{(5-7)}$.

Previous studies have explicitly shown the needs of the mother in performing various roles on top of the process of caring for a child with cancer, including those of women, wife and main caregiver. Women already carry the responsibility of promoting and supporting the child and their family due to multiple social and cultural aspects. As a result, mothers become vulnerable to physical strain, emotional imbalance and family instability, which to some extent indicates a contradiction given the demands of caring for the sick child and for the rest of the family when they are already overloaded for various reasons $\mathrm{s}^{(5,7)}$.

Knowledge on the phenomenon of "maternal overload" still needs to be broadened. Overload in the context of health resulting from care can be defined as the feeling of being burdened triggered in caregivers of patients resulting from the difficulties they encounter in performing this role in their daily lives ${ }^{(8)}$. Authors in the gerontological context define Caregiver Burden as a condition in which providing care for another influences the caregiver's functioning in the emotional, social, financial, physical and spiritual spheres ${ }^{(9)}$.

In the case of families, caregiver burden is the perception of the weight imputed by this role, precisely because they are the main providers of care and support to patients ${ }^{(8,10)}$. There are terms in the literature that are used to characterize the overload resulting from caring for others such as physical wear, suffering, burden or caregiver stress, which in most cases are factors which generate the overload phenomenon $^{(8,10-11)}$

The concept of overload refers to objective aspects, since it involves concrete issues related to physical and mental conditions, and subjective aspects when it involves negative feelings induced in the caregiver by care providing activities ${ }^{(8)}$. Caregiver overload has been addressed in various contexts and population profiles such as in caring for a child with chronic sickness independent of the pathology, as well as in the psychiatric field ${ }^{(2,12)}$.

The term "maternal overload" was not found in a detailed bibliographic review, mainly to characterize the process experienced by mothers as caregivers of children, especially those with cancer. This reinforces the contribution of this study. There is a comparison between the lived experiences of caregivers of patients with chronic diseases with caregiver mothers of cancer patients in the scientific literature. The results emphasize that caregivers of cancer patients suffer more emotional and physical stressors than others, especially along the trajectory of the disease such as moments of remission and relapse, uncertainties and constant fear of loss ${ }^{(10)}$.

The proposal for developing this study had validated instruments which analyze caregiver overload in Brazil as its starting point. Despite having some instruments that evaluate caregiver overload, it was evident that these instruments have some limitations to understanding the experience of maternal overload in caring for children with cancer, especially from the mother's perspective ${ }^{(2,12)}$. The issue of caregiver overload has already been studied from other perspectives such as from the cancer patient themselves and their family members, not only mothers. Furthermore, it has in fact been proven that they overlook or underestimate this issue, meaning that they do not focus on the caregiver overload ${ }^{(13)}$.

In light of the above, this study proposes to explore maternal overload in caring for children with cancer in order to understand this phenomenon through the mother's own perspective. A few questions have arisen from reflecting on the subject:

How do mothers of children with cancer perceive their own overload in caring for their sick child?

In which moments or due to which situations do mothers of children with cancer feel overloaded from caring for their sick child? In addition, which feelings or actions does this overload create for those mothers?

In which way does the existence of a possible experienced or perceived overload affect the lives of these mothers?

Based on these reflections, the present study seeks to understand the experience of maternal overload in caring for children with cancer from the mother's perspective.

\section{METHOD}

\section{StUdDY DESIGN}

The theoretical framework of this study is Symbolic Interactionism (SI), which is a perspective that enables us to understand the way in which individuals define objects, others with whom they interact and how this interpretation process guides individual behavior in specific situations. Its central ideas are based on interaction ${ }^{(14-15)}$. In this study, the mother as the primary caregiver of their child with cancer attributes meanings to her care experience according to her perspective on the situation. The adopted perspective defines their overload experience which is built into the day-to-day care of the child. The attributed meanings are derived from their interaction with the child and the nuclear and extended family, with other patients and health professionals, as well as with the disease, treatment and care environment. The actions of the mother in facing the overload will depend on 
how she has defined this situation from her own interpretations, her SELF, symbols and meanings.

The present study adopted the constructivist model of Grounded Theory (GT), developed by Charmaz ${ }^{(16)}$. This model suggests that neither data nor theories are discovered, but both are constructed "through our involvement and interaction with people, perspectives and research practices”(17).

The relationship between GT and SI is extensively discussed in other qualitative research in the health context $^{(18-19)}$. In this approach, GT enabled understanding the relationship between the actors (mother, child, family and professionals), the scenario (hospitalization) and phenomena (family relationships, cancer, care, treatment, among others). In this sense, it was able to improve the concept of maternal overload to understand the behavior of the mother in facing this phenomenon based on her social experience regarding caring for her child with cancer.

\section{Population}

This study was conducted in a public hospital in the city of São Paulo which is a reference in pediatric cancer care, where about 900 children are treated per month. Six mothers of hospitalized children were interviewed in the second semester of 2017. Mothers of pre-school and school-aged children with cancer who were in a period of more than three months of diagnosis and who were older than 18 years were considered as inclusion criteria. These mothers were selected for the study independently of the child's diagnosis and were required to be fluent in Brazilian Portuguese. Most of the interviewees were married, either in their first or second marriage, aged between 19 and 41 years old, had 1 to 3 children, and an absence of strong family ties. They were identified in interviews/speech by alphanumeric codes followed by a number (I1, I2, etc.).

\section{Data Collection}

Data collection occurred in the second half of 2017 in two phases: the first is characterized as direct and non-participating observation with the use of field notes. The purpose was to promote approximation between the researcher and participants, in addition to experiencing the collection scenario by the observer ${ }^{(20)}$.

The second phase included individual interviews with each mother a priori, with the application of a semi-structured instrument subdivided into two parts. The first part was composed by a genogram and ecomap, which provided a closer bond with the participants and was used "to break the ice". In addition, they provide complementary data on the profile of each mother, their family and social relationships to help the data analysis. The second part of the instrument contained a sequence of key questions applied by the researcher to explore the mother's experiences in caring for her child with cancer.

Saturation occurred through semi-structured interviews up to the moment when it was possible to reject events that no longer contributed to the study, and when the information found was enough to answer the study questions ${ }^{(21)}$.
Mothers were approached individually following the criterion of accessibility or convenience. Mothers who were hospitalized with their children were selected as the target population and represented the participants of this study according to the proposed profile. The researcher selects the elements to which they have access to in this type of non-statistical sampling, assuming that they can somehow represent the universe and respect the inclusion and exclusion criteria of the participants ${ }^{(22)}$.

The interview was guided by the following question proposed to the mothers: - I would like to know your daily routine in managing the care of your sick child, at home and during hospital stays. The content of the interviews was recorded and transcribed verbatim.

The theoretical saturation was based on the understanding of the "intensity of the phenomenon", meaning to identify the dimensions which composed the experience of maternal overload expressed through "beliefs, values, opinions, representations, forms of relation, symbolism, customs, behaviors ..." of the mothers in caring for their child with cancer. It was possible to identify "recidivism and complementarity of information" in the discourse of the participants through an active reflection process, which made it possible to extract the "meanings, the perspective of the subjects, the relations that are present and the interconnections between actors and facts"(23). "Data coding and organization on emerging issues" led to data saturation as new information was not identified ${ }^{(21)}$.

\section{DATA ANALYSIS AND PROCESSING}

The data analysis was assisted by the process of constant data comparison without software aid. Data was initially analyzed line by line, with the objective of generating conceptual codes (initial coding). The analysis process occurred concomitantly with the continuation of the interviews and was performed by the first researcher. Reflections during the analysis were also conducted which generated data in the form of memoranda. The second stage of coding, called focused coding, occurred with the objective of refining the code classification, concentrating on those which stood out by meaning or frequency and which later originated categories. Constant comparison was made between codes and categories throughout the process. Data analysis was validated under guidance from the second researcher.

\section{ETHICAL ASPECTS}

Mothers were informed of the objectives of the study, participation form and other requisites abiding by the ethical requirements of Resolution from the Ministry of Health number 466/12 created by the National Health Council ${ }^{(24)}$. The study was approved by the Research Ethics Committee under number 2.060.781. The interviewees accepted to participate in the study by their own free will. Each interviewee was explained the purpose of the Informed Consent Form (ICF) in detail and it was applied before each interview. The identities of each subject were preserved using the letter I (interviewee) ranging from 1 to $6(\mathrm{I} 1, \mathrm{I} 2$,). 


\section{RESULTS}

The perception of maternal overload experienced in caring for hospitalized children with cancer is a result of a number and accumulation of stressors arising from the care itself and from the children's illness condition, especially due to the cancer diagnosis. Maternal overload in this study was identified as a broad phenomenon expressed in the physical, financial, social, information, moral and emotional areas. The privileged understanding of this phenomenon from those who experience it will be presented in the following seven categories. The schematic representation of the maternal overload experienced by the mother in caring for her child with cancer is represented by Figure 1 below:

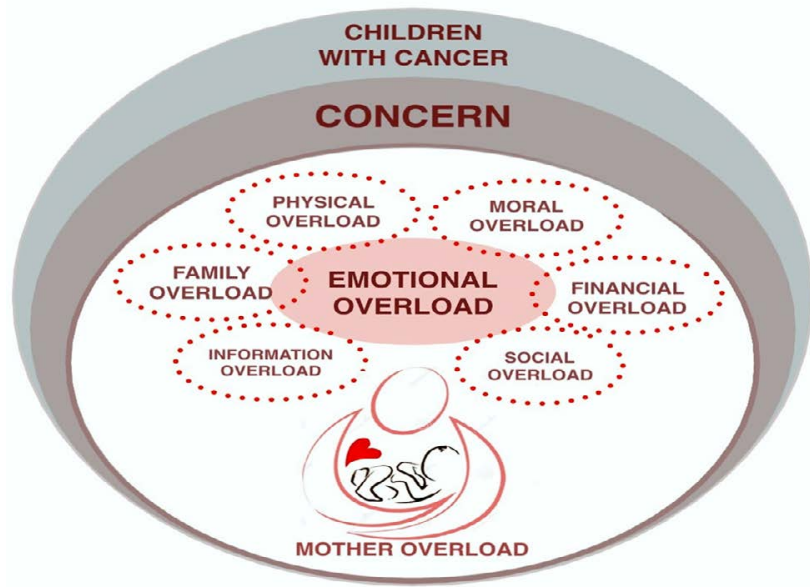

Figure 1 - Maternal overload experienced by mothers in caring for their child with cancer.

The present study clearly revealed that the mother, is constantly submitted to multiple overload factors in the role of caregiver of their child with cancer in the hospitalization process. The unveiled categories are presented below:

\section{EXPERIENCING MATERNAL CARE PERMEATED BY PHYSICAL STRAIN: PHYSICAL OVERLOAD (PO)}

Physical overload was reported by mothers manifested as physical fatigue related to the process of caring for their child in cancer treatment and the need to continually reproduce the same routine of waking up very early and not having a certain time to return home for months, as well as an obligation to resume caring for their child at home. It is clear that there is an accumulation of tasks for these mothers due to the long journeys to the hospital in heavy traffic, the need to carry both the child and their belongings in their arms, a lack of sleep, and having to care for other family members. These are added to the specific needs or complications of the sick child such as complaints of pain and the obligation of prioritizing the care for their child over the mother's own health. The following excerpt from an interview illustrates the mother's effort.

(...) In the morning I come here, I wake up at 4 in the morning, I leave at 5 and then spend the whole day at the clinic undergoing chemotherapy, then go back home and I don't have only the little one, so there is nobody to take care of the home. You have things to do... So on Tuesday, when I don't go with him, I have to take my little girl to school. So, this is the routine, tiring (...) go home. And it's not like coming home, sleeping and waking up. [Imagining how good it would be if life was different, says] (I1).

\section{FACING THE IMPACT OF ECONOMIC IMBALANCE RESULTING FROM CARING FOR THE CHILD: FINANCIAL OVERLOAD ( $\mathrm{FIO})$}

It was clear that mothers who used to work away from the home and participated in providing financial subsistence of the family, either partially or completely, when undertaking the role of caregiver are forced to abandon their jobs and financially depend on other family members, most frequently their partner or husband, and even their own parents or friends, as is shown in this interview excerpt:

(...) And then I had to leave everything, I had to come here to my mother's house, and I became dependent. Because I don't have anywhere to get money from. So it's all very hard, very, very hard (...) Because, one way or the other, I can't help with anything (...) We spend money there [at the hospital] ... sometimes, like now that the volunteers are on holiday, we spend money, we spend a lot there [at the clinic] (...) (I6).

The financial demand reflects a realignment of family roles, especially the couple, since it unveils (among other things) the fact that some mothers feel limited to abdicate a few hours from caring for their child. Some mothers expressed the desire to share this care with their partners, even in order to fulfil other needs such as being with their other children or resting, but ended up feeling frustrated when realizing that this was not possible. The child's father needs to focus on their jobs in order to earn his and his family's subsistence.

\section{Perceiving Dissociative familiy ties: famili OVerLoad (FAO)}

The family issue arises as a stress-causing agent in those mothers' experiences more than as a support and comfort factor. As a result, family relations were perceived to be a trigger for overload from the mothers' perspectives.

Nobody comes, his family doesn't come, neither from his father's side nor mine. So I feel lonely here ... It's like... because it's tiring to be here alone with him, you get tired, you get angry about the food, you get angry about the snacks, you get angry about everytbing! (I4).

\section{EXPERIENCING INTERACTIONS THAT ARE SOMETIMES}

\section{EXHAUSTING AND SOMETIMES LIMITED: SOCIAL OVERLOAD} (SO)

It was possible to identify multiple strenuous factors of social nature in the mothers' reports which are convergent with maternal overload. These were described by the mothers as a set of interactions and abrupt changes in their and their family's lives, reinforced by hospital routine. Mothers summarized the condition of staying in the hospital as if it was "a new home" for each hospitalization, meaning that they and their children somehow need to adapt and improvise a home 
in each hospital stay. Hospitalization is perceived as a symbol of limitation due to the unpredictability of the events that may occur. Having a child with cancer means one is subject to the unforeseen events of a non-programmed hospital stay, having to deal with the complications and side effects of the treatment. It is difficult to maintain social and leisure commitments and social life restrictions naturally take place.

Other symbols of $\mathrm{SO}$ were revealed in this study from the mothers' point of view, some caused by social isolation and the emotional fluctuations experienced during hospital stays, or by the mother and child's vulnerability; these reflect either superficial or invasive interactions to the limits of sociability due to the lack of support and to the meaning attributed to those types of relationships, within and outside the hospital.

(...) this is what it's like, I even created a Whatsapp ${ }^{\circledR}$ group because I was getting messages all the time. For example, he did the myelogram today, so, bum ... I get 10, 15, 20 messages from people who want to know how he coped or what happened. My friends, my cousins sent me messages, my mother... Sent messages asking - Oh, how is $P$ doing? - Did he do the myelography today?... Then another person sent another message. I ended up using an app to explain it properly, there are too many people. Too many people who don't understand and ask too many questions! (...) (I1).

\section{COPING WITH TOO MUCH INFORMATION: INFORMATION OVERLOAD (IO)}

Regarding the amount of information that mothers receive when they stay in the hospital to take care of their children with cancer was the most prevalent and noteworthy complaint during interviews, revealing that they felt extremely distressed and confused with the information received. An excess of information conveyed at the same time, and the way that information is given by healthcare professionals was a source of strain for the mothers. It was clear that education or information provided for healthcare is based on the needs of the professional, and not on the mother's or caregiver's needs. This mother's statement reinforces this perception.

Because I haven't had any help from anyone, because I was uninformed. And in the situation I was in, I thought I was going to lose him (...), right? I had no other solution. In his case, I saw that it wasn't what I had thought that the doctors were telling me, it was not everything that was going to happen, right...? Honestly? I thought I would go mad ... that I was becoming depressed ... Because it all happened so quickly, information after information and I couldn't grasp everything ... Doctors came, gave some information and went away. And I stayed here with my head full of thoughts trying to understand everything (I4).

\section{FEeliNG CONFRONTED IN THEIR VALUES AND BELIEFS: MORAL OVERLOAD (MO)}

The suffering of a child diagnosed with cancer has also revealed itself to those mothers in a different way, meaning having to deal with disrespect or rejection from others, which leads to MO. It was perceived that mothers face issues that go beyond the physical condition of the child, as they had to cope with healthcare professionals' disrespect, they had to face prejudice from people on the street (in public transport, for example), where they noticed that people are scared of "catching" cancer or scared of the child's illness. They define these situations as extremely embarrassing.

Furthermore, the fact of being financially dependent on others has caused a feeling of lack of dignity in those mothers. They also felt disturbed by the judgment of family members about their capacity of being a good mother, and the fact that they were either partially or temporarily housed in relatives' homes was a source of discomfort.

(...) But getting on a bus with a child with cancer is not something nice. First because people stare at you in "that way" as if they were looking at an "animal with seven heads", it looks like they have never seen cancer, that they have only ever seen cancer on television (...) There are mothers who have to go through this ... they get embarrassed (Repeats). There are mothers who get embarrassed (...) (I1).

\section{INTERNALIZING THE BURDEN OF HAVING TO FIGHT CANCER WITH THE CHILD: EMOTIONAL OVERLOAD (EO)}

The emotional impact was characterized as the main element when compared with other types of overload. EO stood out as the most expressive type of overload in reports, being wide and complex. It was unveiled in all interviews as a type of overload inherent to this experience and constant in the lives of mothers of children with cancer. Emotional overload is at the same time determinant of other types of overload, and determined by them, being prevalent for these mothers. It also establishes an indirect cause and effect relationship upon the other types of overload that mothers suffer throughout the process of caring for their children.

From the interviewed mothers' point of view, their life experience, interaction with themselves and with the world, the experience of cancer and the child's hospitalization, this type of overload manifests itself through symptoms and both verbal and non-verbal signs. It is permeated by all sorts of difficulties, by the need to seek help to cope with the stress factors in caring for the child with cancer, but simultaneously steeped in fighting and signifying their roles as mothers.

(...) We think that only the child suffers, and the mother doesn't, the relatives don't suffer? They do suffer!!! (...) Because you don't think about (...) [pause], think about life, about death, about everything you will do, everything you won't do, if I don't do this, if I don't do that (...) This reflects on your body as well (...) Especially in the younger mother, the younger mother [repeats]. There is nothing more to, to (stutters), how can I say (...) so, life experience, right? As in the first time he was hospitalized, I had no idea yet (...) we only have an idea of the thing after we see it (...) (I1).

Oh, it's hard, like, er, she was so little, four or five years old, so it was a very sudden change, right? The treatment was also very hard, very painful. [Replies crying] (...) [Pauses, thinks and replies] Actually, thank God, she responded well, very well. (I2). 
Most mothers were very emotional and reported with extreme sadness that one of the main difficulties experienced by them was coping with the discovery of the child's cancer diagnosis. As stated by one of the mothers, caring for the child with cancer increases the feeling of having to "learn to walk again", which means to re-learn to care and to move on; even if obstacles arise, they need to have the courage to try to overcome it and face the unknown. It means having to deal with uncertainty and fear, abandoning future projects and reassessing their priorities in life.

But when the biopsy result came saying it was cancer, it was a shock for us. Very hard, very, very hard. [Shows emotion with tearful eyes and shaky voice]. [Silence] (...) For us as mothers, like, um, [pause], how (...) [very emotional] (...) For us, what is bad is how the (...) So, er, in reality it is very (...) [emotional pause], as you can tell (...) There are limitations that come, you know! ... So I think she really could be in school, you know, enjoying things, being a child. And when [pause] it's very hard but when you go through a relapse you get very scared, very, very scared. You know when you think nothing is going to work? It's kind of hopeless. So we blame ourselves too much, what have I done wrong, that kind of thing ... suddenly we think like this (I2).

The present study revealed EO in this reality to be the most complex condition experienced by mothers, resulting from their feelings or unfulfilled expectations and desires, against the child's diagnosis or care. The recurrent thought about the impending possibility of the child's death haunts this caregiving experience. It is something so intense that it causes a feeling of losing control of the situation.

The extremely tiring hospital routine culminating in physical overload permeates the emotional condition, as the body is permanently on the alert, in fight mode. Some mothers have expressed their anxiety for this routine to end soon, reinforced by the incessant desire to obtain a cure for their child.

(...) it's very hard on him, he asks to leave, he wants to leave. Every time you ask. So I say that in one day, two days, you know. I try to mask it a little bit to see if he completes his quiet time ... for him not to cry. Because sometimes, you know, he wants to leave, you know, it's [repeats] (...) Very tiring (...) But the biggest strain is emotional strain, I think it's the emotional strain (...) It's really bad to live (...) Because (...) There's so much going on in my head, you know! It's the child, the husband, the home, it's (...) And how they are, my little one (...) (I5).

Signs of emotional overload are revealed by feelings of extreme worry. There were mothers who became physically and emotionally vulnerable due to the context created by the diagnosis. In being closer to their child, they are invaded by recurrent anxiety, which is already expected by adopting an almost "intensive" protective attitude, living in a state of frequent alert associated to their caregiving routine.

Everything that had started. I think that's why I'm not well today (...) I am on tenterhooks. The nurse came today to collect a blood sample from bim this morning. And now in the afternoon, around noon, she came like in a hurry, you know, and as soon as she came to the door my heart was tight, as if it was going to jump from my chest (...) I began to tremble thinking that she was going to give me some news, some bad news (I4).

Discovering new ways to care for their sick child was part of the routine of the mothers whose children with cancer were hospitalized since they define that as their role and responsibility as mothers. It was possible to notice that in addition to trying to cope with this condition, the mothers constantly sought support by identifying strategies to relieve their own overload. The need to fight for their child makes this experience "almost natural" for them, it is part of their role as mothers, and a responsibility which cannot be shared.

\section{DISCUSSION}

The present study clearly unveiled that the mother in the role of caregiver of the child with cancer in the hospitalization process is permanently subjected to multiple overload factors. As in other studies, this study showed evidence that overload is a multidimensional experience ${ }^{(6,8,25)}$.

The physical overload triggered by the caregiving routine of those mothers who accompany their children with cancer during treatment and hospital stays was heightened by their obligations in other contexts such as their other children and the home, and was also similar to the results of other studies ${ }^{(2,7)}$.

The impact of the economic imbalance resulting from the care and treatment of the child culminated in financial overload, since it is usual for the husband to participate solely and exclusively as the source of income to supply the financial needs and cater for the expenses of the family. Thus, there is a realignment of roles and everyday activities within the instrumental functioning of families ${ }^{(2)}$.

It is usual for the mothers to undertake the main caregiver role and to get emotionally involved with the situation, while the fathers (paternal figure) act as providers and tend to emotionally distance themselves. This condition is easily perceived, especially in Latin countries where the mother plays several roles and is expected to develop competence in caring for the sick child ${ }^{(4-6)}$. Given these circumstances, it is necessary to value and foster the father's participation in caring for the sick child as a measure towards sharing this care with the mother; a desire expressed by some mothers in this study ${ }^{(26)}$. Research has revealed the illness of the caregiver on account of the burden of stress, lower satisfaction with life, job loss, break up of relationships, isolation and a decrease in participation, and the loss of purchasing power of the family over time as situations reported by the mothers. Literature also shows evidence of strategies adopted by the father to reinstate normality in caring for the child with cancer in order to cope with the situation ${ }^{(26-28)}$.

The strain on family relationships was very evident caused by the very treatment and hospitalization which these mothers go through, and a certain confinement resulting from this situation showing social overload. This result differs from another study that assessed the consequences of child cancer in family life and which indicated that the social problem for the families was resolved by being together with their child during hospitalization ${ }^{(12)}$. Nevertheless, 
it is worth emphasizing that it is normal for the parents of severely ill children to focus on their children's quality of life, defend them and put their child's needs above their own ${ }^{(26)}$. Another study also revealed the adverse consequences of the social and personal routine of parents, suggesting the need to support specific psychosocial interventions for each phase of the treatment with the purpose of mitigating damage ${ }^{(28)}$.

Contrary to what was revealed by the mothers of this study who felt uncomfortable with the excessive use of social media, a survey which evaluated the impact of the use of the Internet with young people with cancer recognized it as a positive technological resource to understand the health and illness process, find information about symptoms, medications, therapeutic approaches and discuss common concerns with other patients ${ }^{(29)}$.

Research that analyzed the relations, commitment and moral experiences in the care given to children and families from the perspective of Brazilian pediatric nurses argued that there is a certain acknowledgement from the nursing team to work together with the medical team in the sense that both define a purpose to provide care which fulfils the needs of both the child and the family ${ }^{(30)}$. In theory, it is understood that the conduct of extended and therapeutic family care is already being discussed by family nurses. However, in practice, even though care for the family is stimulated in health units, care has been characterized as not humanized and permeated by attitudes which value hospital rules, lack of attention and empathy on the part of professionals ${ }^{(28)}$.

Another study that assessed quality of life and overload of caregivers of children with neoplasms also identified the psychological domain as the most affected one, and in addition to this there was also a prevalence of women as participants in the study, meaning those responsible for caring for other family members ${ }^{(12)}$.

The difficulty of assessing the caregiver's burden in the context of childhood cancer is justified by the fact that it is a complex phenomenon. Child care is something inherent in the age group, depending on the child's illness and vulnerability. This work requires constant and almost full-time vigilance by the mother. In addition, the mother has difficulty expressing her overload when she is experiencing the situation ${ }^{(4,6)}$.

However, it is acknowledged that overload is not always completely declared by those who experience it, highlighting the need to complement the studies with objective assessment tools ${ }^{(2)}$. Similarly, it is believed that this study broadens the knowledge of maternal overload as a subsidy to interventions in family care in the field of pediatric oncology.

\section{CONCLUSION}

This study has broadened the knowledge of maternal overload as a phenomenon experienced by mothers who are caregivers of children with cancer, as told from their own perspectives. The results define how those mothers experience overload during the course of their children's illness and how they express their needs resulting from such overload. Thus, this study may help to delineate the pathway to interventions which can ease the impact on mothers in this context, considering family-centered care. In this regard, seven types of overload were identified from the mothers' narratives in this investigation. Despite mothers being the target for many types of overload, this study strengthened the social and emotional domains as being most significant in this experience.

In the nature of reflection, it is possible to observe that it is plausible to have a substitution of the caregiver for the care practice of adults in case the latter perceive themselves as overloaded; however, in children's care it is shown that the mother does not allow herself to be completely substituted when in such condition. It was noticed that mothers give up their own care when filled with feelings of true love, giving their own life towards the well-being of her child.

Through an analysis of the scientific literature that originated this study, it is possible to suggest general strategies and without the pretension to fulfil them in a unique way, which can alleviate the burden in caring for children with cancer, such as: appoint a nurse specialized in family care to perform visits and bedside care, and thus proactively guide the family, establish ties of trust and good relationships to minimize SO and EO; offer help concerning leisure and entertainment activities; suggest actions in hospital service that are aligned to a multidisciplinary team, since mothers have expressed the need for care in a bio-psycho-social way.

These findings suggest that the knowledge of maternal overload does not end with this study, which reported on perspectives of mothers who undergo treatment in only one healthcare facility. We believe that other mothers can be approached in different realities in order to broaden the perception of an issue as complex as maternal overload. Another limitation of this study that needs to be considered is that these results only reflect the perspective of a single-family member. In this sense, further studies could be carried out with other family members in order to broaden and improve the perspective on maternal overload and to contribute to improving further assessment instruments.

\section{RESUMO}

Objetivo: Compreender a experiência da sobrecarga materna no cuidado dos filhos com câncer do ponto de vista da mãe. Método: O Interacionismo Simbólico foi adotado como um marco teórico e a Teoria Fundamentada nos Dados, como marco metodológico. O estudo foi conduzido em um hospital público, que é referência em oncologia pediátrica. Os dados foram coletados de seis mães por meio de entrevistas semiestruturadas no segundo semestre de 2017. Resultados: As mães das crianças com câncer atribuíram significado à experiência do cuidado quando tentaram lidar com a informação emocional, social, física, financeira, relacionada à família e a sobrecarga moral. A sobrecarga materna emerge como um processo inter-relacional dinâmico entre os vários tipos de sobrecarga. Conclusão: A figura materna é a pessoa principal envolvida no cuidado e experimenta sobrecarga no cuidado com seus filhos doentes, enfrentando limitações e responsabilidades. A pesquisa agiu como um elemento-chave para ampliar a análise e intervenção do enfermeiro familiar, não apenas contribuindo para o construto teórico relacionado à sobrecarga materna, mas também e principalmente para o escopo da prática no cuidado com o paciente. 


\section{DESCRITORES}

Criança; Neoplasias; Mães; Cuidadores; Relações Familiares; Enfermagem Oncológica.

\section{RESUMEN}

Objetivo: Comprender la experiencia de la sobrecarga materna en el cuidado a los hijos con cáncer desde el punto de vista de la madre. Método: El Interaccionismo Simbólico fue adoptado como un marco teórico y la Teoría Fundamentada en los Datos, como marco metodológico. Se llevó a cabo el estudio en un hospital público, que es referencia en oncología pediátrica. Se recogieron los datos de seis madres mediante entrevistas semiestructuradas en el segundo semestre de 2017. Resultados: Las madres de los niños con cáncer atribuyeron significado a la experiencia del cuidado cuando intentaron manejar la información emotiva, social, física, financiera, relacionada con la familia y la sobrecarga moral. La sobrecarga materna surge como un proceso interrelacional dinámico entre los distintos tipos de sobrecarga. Conclusión: La figura materna es la persona principal involucrada en el cuidado y experimenta sobrecarga en el cuidado a sus hijos enfermos, enfrentando limitaciones y responsabilidades. La encuesta actuó como un elemento clave para ampliar el análisis y la intervención del enfermero familiar, no solo contribuyendo al constructo teórico relacionado con la sobrecarga materna, sino también y especialmente al marco de la práctica en el cuidado con el paciente.

\section{DESCRIPTORES}

Nino; Neoplasias; Madres; Cuidadores; Relaciones Familiares; Enfermería Oncológica.

\section{REFERENCES}

1. Brasil. Ministério da Saúde; Instituto Nacional do Câncer José Alencar Gomes da Silva. Tipos de câncer: infantojuvenil [Internet]. Rio de Janeiro: INCA; 2019 [citado 2019 jan. 27]. Disponível em: http://www2.inca.gov.br/wps/wcm/connect/tiposdecancer/site/home/infantil

2. Macedo EC, Silva LR, Paiva MS, Ramos MN. Burden and quality of life of mothers of children and adolescents with chronic illnesses: an integrative review. Rev Latino Am Enfermagem [Internet]. 2015 [cited 2019 Jan 27];23(4):769-77. Available from: http://www.scielo.br/ scielo.php?script=sci_arttext\&pid=S0104-11692015000400769\&lng=en\&nrm=iso\&tlng=en

3. Modanloo S, Rohani C, Shirinabadi Farahani A, Vasli P, Pourhosseingholi A. General family function as a predictor of quality of life in parents of children with cancer. J Pediatr Nurs. 2019;44:e2-e8. DOI: 10.1016/j.pedn.2018.08.013.

4. Carreño Moreno S, Arias Rojas M. Competencia para cuidar em el hogar y sobrecarga em el cuidador del ninõ com cáncer. Gac Mex Oncol. 2016;15(6):336-43. DOI: https://doi.org/10.1016/j.gamo.2016.09.009

5. Rafii F, Oskouie F, Shoghi M. Caring for a child with cancer: impact on mother's health. Asian Pac J Cancer Prev. 2014;15(4):1731-8. DOI:10.7314/APJCP.2014.15.4.1731

6. Montero Pardo X, Jurado Cárdenas S, Méndez Venegas J. Variables that predict the appearance of burden in informal primary caregivers of children with cancer. Psicooncología. 2015;12(1):67-86. DOI: 10.5209/rev_PSIC.2015.v12.n1.48905

7. Moules NJ, Estefan A, McCaffrey G, Tapp DM, Strother D. Taking one for the team: examining the effects of childhood cancer on the parental subsystem-part 2. J Fam Nurs. 2016;22(4):540-58. DOI:10.1177/1074840716675985

8. Nolasco M, Bandeira M, Oliveira MS, Vidal CEL. Sobrecarga de familiares cuidadores em relação ao diagnóstico de pacientes psiquiátricos. J Bras Psiquiatr [Internet]. 2014 [citado 2018 ago. 8];63(2):89-97. Disponível em: http://www.scielo.br/scielo.php?pid=S004720852014000200089\&script=sci_abstract\&tlng=pt

9. Adelman RD, Tmanova LL, Delgado D, Lachs MS. Caregiver burden: a clinical review. JAMA. 2014;311(10):1052-60. DOI: 10.1001/ jama.2014.304

10. Shaffer KM, Kim Y, Carver CS, Cannady RS. Effects of caregiving status and changes in depressive symptoms on development of physical morbidity among long-term cancer caregivers. Health Psychol [Internet]. 2017[cited 2018 Aug 8];36(8):770-8. Available from: https:// www.ncbi.nlm.nih.gov/pmc/articles/PMC5551905/

11. Molina RCM, Higarashi IH, Marcon SS. Importância atribuida à rede de suporte social por mães com filhos em unidade intensiva. Esc Anna Nery [Internet]. 2014;18(1):60-7. Disponível em: http://www.scielo.br/scielo.php?script=sci_arttext\&pid=S1414-81452014000100060

12. Andrade SFO, Alves RF, Melo MO, Rodrigues MJ. Qualidade de vida e sobrecarga de cuidadores de crianças com câncer. Psicol Ciênc Prof [Internet]. 2014 [citado 2018 ago. 8];34(4):1014-31. Disponível em: http://www.scielo.br/scielo.php?script=sci_arttext\&pid=S141498932014000401014\&lng=en\&nrm=iso\&tlng=pt

13. Shin JY, Lim JW, Shin DW, Kim SY, Yang HK, Cho J, et al. Underestimated caregiver burden by cancer patients and its association with quality of life, depression and anxiety among caregivers. Eur J Cancer Care (Engl). 2018;27(2):e12814. DOI: https://doi.org/10.1111/ ecc. 12814

14. Charon JM. Symbolic interactionism: an introduction, an interpretation, an integration. 10th ed. Engleward Cliffs: Prentice Hall; 2010.

15. Blumer H. Simbolic interactionism. Engleward Cliffs: Prentice Hall; 1969.

16. Charmaz K. Constructing Grounded Theory: a pratical guide trough qualitative analysis. Thousand Oaks: Sage; 2006.

17. Santos JLGD, Cunha K, Adamy EK, Backes MTS, Leite JL, Sousa FGM. Data analysis: comparison between the different methodological perspectives of the Grounded Theory. Rev Esc Enferm USP. 2018;52:e03303. DOI: http://dx.doi.org/10.1590/s1980-220x2017021803303

18. Gabatz RIB, Schwartz E, Milbrath VM, Zillmer JGV, Neves ET. Data analysis: comparison between the different methodological perspectives of the Grounded Theory. Texto Contexto Enferm [Internet]. 2017 [cited 2018 Aug 8];26(4):e1940017. Available from: http://www.scielo. br/scielo.php?pid=S0080-62342018000100600\&script=sci_arttext\&tlng=en

19. Silva GWS, Enders BC, Sousa FGM, Sena JF, Santos RC, Silva AB. Teoria fundamentada nos dados em teses e dissertações da enfermagem brasileira. Texto Contexto Enferm [Internet]. 2018[citado 2018 ago. 8];27(4):e3870017. Disponível em: http://www.scielo.br/pdf/tce/ v27n4/0104-0707-tce-27-04-e3870017.pdf

20. Matheus MCC, Fustinoni SM. Pesquisa qualitativa em enfermagem. São Paulo: Hucitec; 2014. 
21. Prodanov CC, Freitas EC. Metodologia do trabalho científico: métodos e técnicas da pesquisa e do trabalho acadêmico. $2^{\text {a }}$ ed. Novo Hamburgo: Universidade Feevale; 2013.

22. Minayo MCS. Amostragem e saturação em pesquisa qualitativa: consensos e controvérsias. Rev Pesq Qual [Internet]. 2017 [citado 2018 ago. 8];5(7):01-12. Disponível em: https://editora.sepq.org.br/index.php/rpq/article/view/82/59

23. Nascimento LCN, Souza TV, Oliveira ICDS, Moraes JRMM, Aguiar RCB, Silva LFD. Theoretical saturation in qualitative research: an experience report in interview with schoolchildren. Rev Bras Enferm [Internet]. 2018 [cited 2018 Aug 8];71(1):228-33. Available from: http://www.scielo.br/scielo.php?script=sci_arttext\&pid=S0034-71672018000100228

24. Brasil. Ministério da Saúde; Conselho Nacional de Saúde. Resolução n.466, de 12 de dezembro de 2012. Dispõe sobre diretrizes e normas regulamentadoras sobre pesquisas envolvendo seres humanos [Internet]. Brasília; 2013 [citado 2018 ago. 8]. Disponível em: http:// conselho.saude.gov.br/resolucoes/2012/Reso466.pdf

25. Batista CF, Bandeira M, Oliveira DR. Fatores associados à sobrecarga subjetiva de homens e mulheres cuidadores de pacientes psiquiátricos. Ciênc Saúde Coletiva [Internet]. 2015 [citado 2018 ago. 8];20(9):2857-66. Disponível em: http://www.scielo.br/pdf/csc/v20n9/1413-8123csc-20-09-2857.pdf

26. Polita NB, Alvarenga WA, Leite ACAB, Araújo JS, Santos LBPAD, Zago MMF, et al. Care provided by the father to the child with cancer under the influence of masculinities: qualitative meta-synthesis. Rev Bras Enferm [Internet]. 2018 [cited 2018 Aug 8];71(1):185-94. Available from: http://www.scielo.br/scielo.php?script=sci_arttext\&pid=S0034-71672018000100185

27. Melo EM, Ferreira PL, Lima RA, Mello DF. The involvement of parents in the healthcare provided to hospitalized children. Rev Latino Am Enfermagem [Internet]. 2014 [cited 2018 Aug 8];22(3):432-9. Available from: http://www.scielo.br/pdf/rlae/v22n3/0104-1169rlae-22-03-00432.pdf

28. Laidsaar-Powell R, Butow P, Boyle F, Juraskova I. Managing challenging interactions with family caregivers in the cancer setting: guidelines for clinicians (TRIO Guidelines-2). Patient Educ Couns. 2018;101(6):983-94. DOI: 10.1016/j.pec.2018.01.020

29. Borghi CA, Szylit R, Ichikawa CRF, Baliza MF, Camara UTJ, Frizzo HCF. O uso das redes sociais virtuais como um instrumento de cuidado para adolescentes hospitalizados. Esc Anna Nery [Internet]. 2018 [citado 2018 ago 8];22(1):e20170159. Disponível em: http://www.scielo. br/pdf/ean/v22n1/pt_1414-8145-ean-2177-9465-EAN-2017-0159.pdf

30. Santos RP, Neves ET, Carnevale F. The moral experiences of pediatric nurses in Brazil: engagement and relationships. Nurs Ethics. 2019;26(5):1566-78. DOI: 10.1177/0969733017753744 